\title{
ANALISIS FAKTOR KEJADIAN PHLEBITIS DENGAN SIMULASI MODEL FISIS ALAT TERAPI INTRAVENA
}

\author{
Menik Dwi Kurniatie ${ }^{1)}$ \\ Prodi Teknik Biomedis, Fakultas Teknik, Universitas Dian Nuswantoro \\ nikdwika@gmail.com
}

\begin{abstract}
Intravenous therapy through long-term infusion is at risk for complications such as phlebitis. The influence of medical factors with a history of hypertension and mechanical factors based on the location of the position of infusion is the main study of the causes of phlebitis. One of the causes of phlebitis is the flow of intravenous fluids which is not proportional to the volume of infusion fluid. Intravenous Therapy Devices with the aim of assessing the physical phenomena modeling experiments intravenous therapy with the theory of fluid mechanics and prove the existence of linkage patient's blood pressure and height of intravenous fluid drop rate. The research method is experimental with the physical modeling of intravenous therapeutic devices.
\end{abstract}

Physical model of intravenous therapy devices using a manometer to measure the pressure tube as diastolic pressure and variation on fluid infusion used was $\mathrm{NaCl} 0.9 \%$ and Glucose $5 \%$. The results of this research was obtained diastolic pressure below $80 \mathrm{mmHg}$ produced a drop rate of fluid infusion is almost constant with a maximum height of a standard intravena pole 1meter, while at an altitude above the altitude variation of normal use by $90 \mathrm{mmHg}$ diastolic pressure with height variations of 1.1 to 1.3 meters yield drop rate a linear of infusion liquid to height variations. So to prevent turbulence of intravenous fluids (the cause of phlebitis) by increasing the location standard for infusion.

Keywords : intravenous, phlebitis

\section{PENDAHULUAN}

Terapi intravena melalui pemasangan infus berguna untuk mengobati barbagai kondisi pasien di lingkungan perawatan rumah sakit, namun beberapa masalah bisa muncul akibat adanya terapi tersebut (Seleky, Kumat, \& Mulyadi, 2016). Isfandiari dan Akbar (2018) juga menjelaskan bahwa pasien yang mendapatkan terapi intravena dalam jangka panjang beresiko untuk terjadinya komplikasi seperti phlebitis akibat adanya trauma pada vena selama pemasangan infus.

Menurut Alexander, et al, (2010) dalam Pradini, P.C.A., (2016) menjelaskan bahwa phlebitis adalah reaksi inflamasi yang terjadi pada pembuluh darah vena yang ditandai dengan nyeri, kemerahan, bengkak, panas, indurasi (pengerasan) pada daerah tusukan dan pengerasan sepanjang pembuluh darah vena. Phlebitis berpotensial membahayakan karena bekuan darah (tromboflebitis) dapat terjadi dan pada beberapa kasus dapat menyebabkan pembentukan emboli (Perry \& Potter, 2005). Data dari CDC (2017) dalam Isfandiari dan Akbar (2018) menunjukkan bahwa kejadian phlebitis menempati urutan keempat sebagai infeksi yang sering ditemukan pada pasien selama menjalani masa perawatan. Angka kejadian phlebitis tertinggi terdapat di negaranegara berkembang seperti India $(27,91 \%)$, Iran 
$(14,21 \%), \quad$ Malaysia $\quad(12,70 \%), \quad$ Filipina $(10,10 \%)$, dan Indonesia $(9,80 \%)$.

Data statistik yang didapat dari Yayasan Kesehatan mengenai infeksi nosocomial phlebitis menempati peringkat pertama infeksi nosokomikal di Indonesia dibandingkan infeksi lainnya yaitu sebanyak 16.435 kejadian phlebitis dari 588.328 pasien beresiko di Rumah Sakit Umum di Indonesia atau lebih kurang 2,8 $\%$ dan sebanyak $293 \%$ kejadian phlebitis dari 18.800 pasien yang beresiko di Rumah Sakit khusus atau swasta di Indonesia pada tahun 2006 atau lebih kurang 1,5\% (Depkes RI, 2007).

Menurut Darmadi (2008) infeksi nosokomikal merupakan infeksi yang terjadi pada pasien ketika berada di rumah sakit atau ketika berada di fasilitas kesehatan lainnya. Suatu penelitian yang dilakukan WHO menunjukkan bahwa sekitar $8,7 \%$ dari 55 rumah sakit dari 14 negara yang berasal dari Eropa, Timur Tengah, asia Tenggara, dan Pasifik menunjukkan adanya infeksi nosokomikal Hospital Acquired Infection (HAIs) dan untuk Asia Tenggara sebanyak 10,0\% ( Putri, 2016).

Angka kejadian phlebitis merupakan indikator mutu keperawatan. Angka kejadian infeksi nosokomikal juga telah dijadikan salah satu tolak ukur mutu pelayanan di rumah sakit. Infeksi nosokomikal merupakna infeksi yang terjadi pada pasien ketika berada dirumah sakit atau berada di fasilitas kesehatan lainnya. Dari sekian banyak jenis infeksi nosokomikal, phlebitis menempati peringkat pertama disbanding dengan infeksi lainnya (Depkes RI, 2013).

Angka kejadian phlebitis di Rumah sakit AR. Bunda Prabumulih turun naik, pada bulan Januari $8 \%$ kemudian pada bulan Februari 2014 jumlah pasien yang phlebitis meningkat sebesar $17 \%$, dan angka ini lebih besar dari bulan yang lainnya (Rizky, 2016). Menurut Isfandiari dan Akbar (2018) dalam data RSU Haji Surabaya (2016) bahwa data laporan kejadian phlebitis di RSU Haji Surabaya periode tahun 2015 sampai dengan
2016 didapatkan persentase kejadian phlebitis yang masih diatas standar yang ditentukan oleh Menkes RI yaitu sebesar 3,20 \% ditahun 2015 dan 2,26 \% ditahun 2016. Rahayu dan Kadri (2016) juga menjelaskan bahwa belum semua tenaga kesehatan menyadari akan pentingnya melakukan tindakan pencegahan terhadap penyakit phlebitis, oleh karena itu masih ditemukannya angka kejadian phlebitis yang melebihi standar.

Berdasarkan sumber laporan data beberapa Rumah sakit maka pembahasan tentang penyebab dari kejadian phlebitis masih terus berkembang. Menurut Rizky (2016) karakteristik angka kejadian phlebitis yang terjadi berdasarkan penyebabnya masih variative, penyebab yang sering terjadi pada pasien sering dipengaruhi diantaranya adalah faktor usia, penyakit kronis (misalnya: diabetes, hipertensi, gagal ginjal kronik, dan kanker, jenis cairan (osmolaritas cairan) dan juga Teknik pemasangan yang salah.

Berdasarkan latar belakang tersebut maka tujuan dari penelitian ini adalah mengetahui dan menganalisa faktor-faktor yang berhubungan dengan kejadian phlebitis yang dipengaruhi kondisi pasien hipertensi dengan membuat suatu simulasi pemodelan fisis alat terapi intravena terhadap keterkaitan pengaruh ketinggian atau lokasi pemasangan cairan infus yang tepat sehingga dapat mencegah adanya kejadian phlebitis.

Penelitian ini memberikan manfaat bagi perkembangan ilmu kesehatan khususnya bagi ilmu keperawatan sebagai masukan bagi perawat berupa informasi tambahan bahwa bagaimana menganalisis faktor adanya pengaruh kejadian phlebitis terhadap nilai tekanan darah pasien dan manfaat yang kedua bagi peneliti berikutnya dapat dijadikan sebagai data, informasi dasar, dan evidence based serta penerapan aplikasi dari teori mekanika fluida terhadap kaitannya pembuluh

\section{METODOLOGI PENELITIAN}

Jenis penelitian ini adalah observasional analitik dan eksperimental 
analitik. Observasional analitik dengan melakukan observasi langsung pada pihak perawat dalam menentukan apakah faktor mekanik mempengaruhi pemberian cairan infus. Kemudian dengan metode eksperimental dibuat sebuah model fisis terapi intravena (seperti pada Gambar 2). .Data eksperimental berasal dari pemodelan fisis alat terapi intravena tersebut akan diolah dengan kajian pustaka mengenai teori Mekanika Fluida.

Tekanan diastolik disimulasikan dengan botol bertekanan sebagai model pembuluh vena. bertekanan $p_{1}$ (tekanan diastolik), seperti yang ditampilkan pada Gambar 1. Hubungan antara tekanan $p_{1}$ terhadap ketinggian air, seperti yang disajikan pada Persamaan (1).

$$
p_{1}=p_{0}+\rho g h_{0}
$$

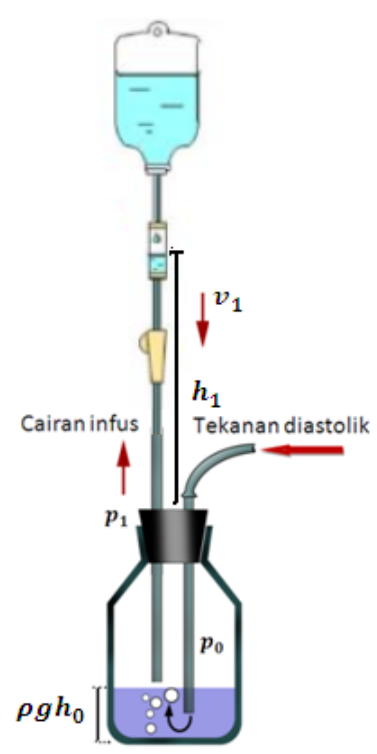

Gambar 1. Botol bertekanan pemodelan
pembuluh vena

Pengaturan nilai tekanan diastolik tersebut dilakukan dengan menggunakan pompa yang diukur dengan Manometer (M). Tekanan dalam botol yang menggambarkan tekanan diastolik sebesar $p_{1}$ mengakibatkan air dalam botol naik ke dalam selang hingga mencapai ketinggian $h_{1}$, seperti yang disajikan pada Gambar 3.4. Besar nilai tekanan $p_{1}$ dari Persamaan (1) dengan ketinggian $h_{1}$ dan laju tetesan $v_{1}$, seperti yang disajikan pada Persamaan (2).

$$
p_{1}+\rho g h_{1}+1 / 2 \rho v_{1}^{2}
$$

Infus set yang sekaligus terhubung pada botol infus digantung pada statif dengan ketinggian tertentu $\left(h_{2}\right)$. Nilai tekanan cairan infus diujung lubang botol adalah $p_{2}$ yang merupakan tekanan hidrostatik cairan sebagai fungsi ketinggian $\left(h_{2}\right)$, seperti yang disajikan pada Persamaan (3).

$$
p_{2}=p_{0}+\rho g h_{2}
$$

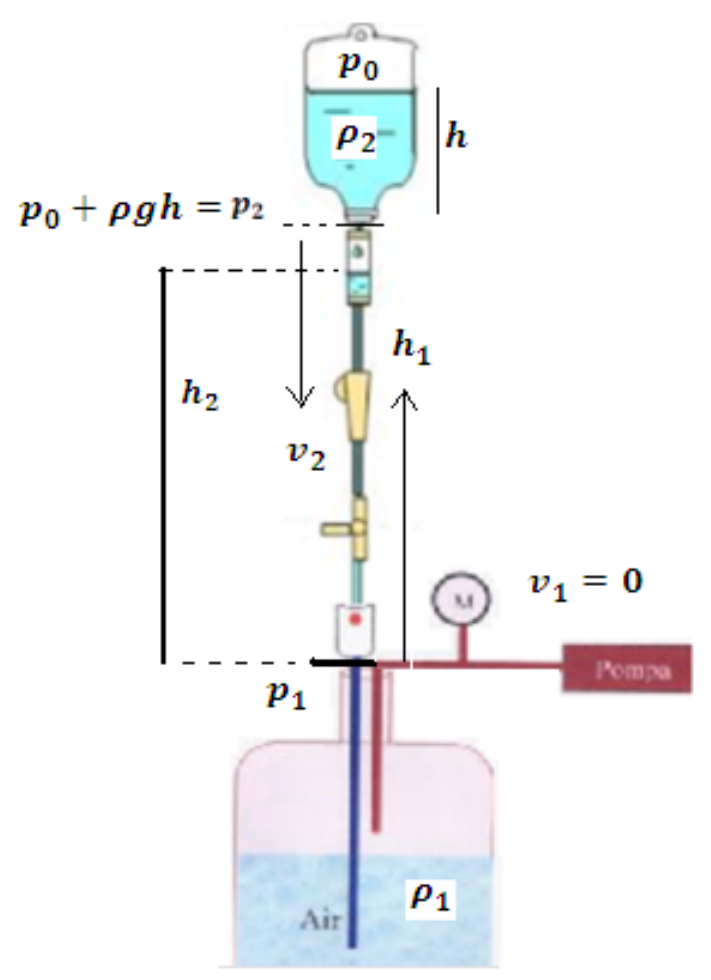

Gambar 2 . Model Fisis Terapi Intravena dengan Variasi Ketinggian

Data hasil penelitian diolah dalam bentuk tabel dan dianalisis menggunakan metode regresi untuk menganalisis nilai signifikan adanya pengaruh faktor mekanik terkait posisi maksimal pemasangan infus terhadap pengaruh nilai tekanan darah tinggi pasien. Bahan dan alat penelitian dari pemodelan alat fisis terapi intravena terdiri dari bahan cairan infus diantaranya Larutan $\mathrm{NaCl}$ 0,45\% dan Larutan Glukosa 5\%. Instrument penelitian terdiri dari stopwatch, manometer, satu perangkat alat 
infus, dan satu botol bertekanan sebagai model pembuluh vena. Penelitian ini dilaksanakan pada Bulan April-Mei Tahun 2018 di Laboratorium Rehabilitasi Medis, Fakultas Teknik Universitas Dian Nuswantoro.

Data pertama adalah pengamatan laju aliran cairan infus dengan perilaku ketinggian konstan untuk mengetahui adanya perubahan tekanan (Pada Tabel 1). Data kedua adalah pengambilan data hasil pengamatan laju aliran cairan infus dengan perilaku tekanan konstan untuk mengetahui adanya pengaruh perubahan ketinggian (Pada Tabel 2).

\section{HASIL DAN PEMBAHASAN}

\section{Model fisis aliran terapi intravena}

Model fisis alat terapi intravena seperti yang disajikan pada Gambar 2 merupakan pemodelan mekanisme kerja alat infus yang digunakan untuk mengetahui fenomenafenomena fisis pada eksperimen yang ada kaitannya dengan konsep mekanika fluida. Pada cairan infus diperlukan perhitungan laju tetesan untuk mengkaji aliran cairan infus yang mengacu pada tekanan statik di dalam cairan. Statika cairan mencakup kajian kondisi cairan dalam keadaan kesetimbangan yang stabil.

Dari hasil penelitian dan perhitungan diperoleh nilai laju tetesan cairan infus dengan variasi tekanan dan ketinggian masing-masing memiliki pengaruh terhadap laju tetesan cairan infus seperti yang disajikan pada Tabel 1 dan Tabel 2. Penelitian pengukuran kalajuan tetesan cairan infus untuk variasi tekanan, dengan ketinggian tiang infus yang digunakan adalah ketinggian tiang infus batas maksimum normalnya yaitu 1 meter. Ketinggian tiang infus normalnya, yaitu 30-36 inci atau (76-100) $\mathrm{cm}$. Pada ketinggian tiang infus 1 meter dan cairan infus mulai tidak menetes, ketika tekanan dari botol bertekanan (manometer) $\geq 80$ mmHg. Sehingga variasi tekanan yang diberikan anatara $45 \mathrm{mmHg}-75 \mathrm{mmHg}$ (kurang dari $80 \mathrm{mmHg}$ ).
Hasil akhir yang diperoleh dalam penelitian ini adalah laju alir cairan infus dengan parameter-parameter pendukung dalam kajian fisis diantaranya dipengaruhi oleh tekanan aliran dan ketinggian lokasi pemasangan cairan infus. Hasil pengamatan kedua dengan membandingkan laju aliran caian infus pada masing-masing cairan dengan variasi jenis cairan berdasarkan kebutuhan nutrisi pasien.

\section{Laju alir cairan infus dengan variasi tekanan}

Tabel 1 menunjukkan nilai laju tetesan cairan infus dengan variasi tekanan. Tekanan dari manometer yang diberikan kurang dari 80 mmHg yaitu antara 45-75 mmHg agar cairan infus mengalir. Hal ini disebabkan tekanan manometer mencapai maksimum hingga cairan pada botol infus berhenti sebesar $80 \mathrm{mmHg}$. Untuk variasi tekanan, ketinggian $h_{2}$ adalah 1 meter yang diukur dari permukaan tetesan cairan infus hingga sejajar letak ujung jarum. $h_{2}$ merupakan ketinggian normal batas maksimum yang digunakan pihak rumah sakit.

Berdasarkan hasil perhitungan diperoleh nilai laju tetesan cairan untuk masingmasing variasi tekanan antara $45-70 \mathrm{mmHg}$ berbanding terbalik dengan nilai tekanannya. Sesuai dengan Prinsip Bernoulli yang menyatakan bahwa di mana kecepatan fluida tinggi, tekanan rendah, dan di mana kecepatan rendah, tekanan tinggi (Giancoli, 2001). Laju tetesan cairan infus menunjukkan linearitas dengan variasi tekanan, seperti pada Gambar 2. Berdasarkan hasil regresi linier antara laju tetesan cairan infus terhadap variasi tekanan untuk masing-masing cairan memiliki nilai $R^{2} \sim 1$ yang menunjukkan linearitas hubungan antara laju tetesan terhadap tekanan diastolik. 
Tabel 1. Hasil perhitungan laju alir cairan infus dengan variasi tekanan di atas keadaan normal yaitu tekanan infus lebih dari 1 meter

\begin{tabular}{|c|c|c|c|}
\hline \multirow{2}{*}{ No. } & \multirow{2}{*}{$\begin{array}{c}\text { Tekanan } \\
(\mathrm{mmHg})\end{array}$} & \multicolumn{2}{|c|}{$\begin{array}{c}\text { Nilai Laju tetesan Cairan } \\
\text { Infus } \\
\text { (ketinggian konstan) }\end{array}$} \\
\cline { 3 - 4 } & & $\begin{array}{c}\text { Larutan } \\
\text { NaCl 0,9 \% }\end{array}$ & $\begin{array}{c}\text { Larutan } \\
\text { Glukosa 5 \% }\end{array}$ \\
\hline 1 & 75 & 3,06413 & 3,10227 \\
\hline 2 & 73 & 3,14995 & 3,18707 \\
\hline 3 & 70 & 3,27447 & 3,31019 \\
\hline 4 & 68 & 3,35492 & 3,38979 \\
\hline 5 & 65 & 3,47210 & 3,50580 \\
\hline 6 & 63 & 3,54807 & 3,58106 \\
\hline 7 & 60 & 3,65907 & 3,69107 \\
\hline 8 & 55 & 3,83693 & 3,86746 \\
\hline 9 & 50 & 4,00691 & 4,03616 \\
\hline 10 & 45 & 4,16997 & 4,19808 \\
\hline
\end{tabular}

Nilai gradien dari hasil regresi, seperti yang ditampilkan pada Gambar 2, pada larutan $\mathrm{NaCl} 0,9 \%$ dan larutan Glukosa $5 \%$ bernilai negatif yang menandakan bahwasannya kenaikan nilai tekanan diastolik yang diberikan berbanding terbalik terhadap nilai laju tetesannya. Semakin besar tekanan darah pasien maka mempengaruhi laju tetesan cairan infus akan semakin lambat. Selain itu, hasil regresi linear bukan hanya sebagai pembanding melainkan sebagai rumusan untuk menentukan pada tekanan berapakah, kelajuan tetesan cairan infus dapat ditentukan.

\section{Laju alir cairan infus dengan variasi ketinggian}

Pada pengukuran kalajuan aliran cairan infus untuk variasi ketinggian, tekanan manometer maksimum agar cairan pada botol infus berhenti mengalir yaitu bernilai $80 \mathrm{mmHg}$ dan otomatis besarnya sama dengan nilai tekanan hidrostatik pada botol cairan infus. Proses pengambilan data dengan variasi ketinggian di mulai pada ketinggian 1 meter maka tekanan manometer diturunkan menjadi
$65 \mathrm{mmHg}$. Interval variasi ketinggian sebesar 0,05 meter sebanyak 3 variasi yaitu $0,9 \mathrm{~m}, 0,95$ $\mathrm{m}$ dan $1 \mathrm{~m}$. Nilai laju tetesan cairan infus dari Tabel 1 dan Tabel 2 diperoleh tanpa memperhitungkan adanya geseran atau gesekan, sehingga selisih nilai laju tetesan tidak berbeda jauh.

Tabel 2. Hasil perhitungan laju alir cairan infus dengan variasi ketinggian di

\begin{tabular}{|c|c|c|c|}
\hline No. & \multirow{2}{*}{$\begin{array}{c}\text { Ketinggian } \\
(\text { meter })\end{array}$} & \multicolumn{2}{|c|}{$\begin{array}{r}\text { Nilai Laju tetesan Cairan } \\
\text { Infus }\left(h_{2} \text { konstan }\right)\end{array}$} \\
\cline { 3 - 4 } & & $\begin{array}{c}\text { Larutan } \\
\text { NaCl 0,9 \% }\end{array}$ & $\begin{array}{c}\text { Larutan } \\
\text { Glukosa } 5 \%\end{array}$ \\
\hline 1 & 1 & 2,8209 & 2,8416 \\
\hline 2 & 0,95 & 2,6415 & 2,6637 \\
\hline 3 & 0,9 & 2,4489 & 2,4729 \\
\hline
\end{tabular}

Pada Tabel 2 didapatkan hasil laju tetesan cairan infus besarnya sebanding dengan variasi ketinggian, maka dapat ditunjukan linearitas hubungan keduanya tersebut seperti pada Gambar 3.

Untuk variasi ketinggian dengan tekanan yang lebih besar dari tekanan maksimum manometer sebesar $80 \mathrm{mmHg}$, solusi yang dilakukan agar aliran infus tetap mengalir dengan mengubah ketinggian posisi botol cairan infus $h_{2}$ lebih dari 1 meter. Hal ini berlaku untuk kasus pasien memiliki tekanan darah tinggi, dimana aliran darah melalui pembuluh darah yang lebih cepat dibandingkan pasien bertekanan darah normal. Maka dibutuhkan besar tekanan pada botol cairan infus yang melebihi tekanan darah pada pasien. Ketika solusi ini tidak digunakan, maka ada kemungkinan darah pasien akan mengalir masuk pada selang cairan infus yang mengakibatkan terlepasnya selang infus karena arah tekanan berlawanan sangat dominan. Hal ini disebabkan tekanan diastolik $>>$ tekanan hidrostatik di dalam botol cairan infus. Kerugian lainnya ketika tekanan diastolik > tekanan hidrostatik dengan selisih kedua tekanan tidak berbeda jauh mengakibatkan terjadinya aliran turbulensi pada pembuluh darah, dimana aliran darah termampatkan 
karena ada pengaruh tekanan aliran caiaran infus yang arahnya berlawanan pada aliran darah di dalam pembuluh darah. Maka sering terjadi pecahnya pembuluh darah bagi para pengguna infus dan dampak lainnya semacam iritasi ataupun pembengkakan.

Tabel 3. Hasil perhitungan laju alir cairan infus dengan variasi ketinggian di atas keadaan normal yaitu ketinggian infus lebih dari 1 meter

\begin{tabular}{|c|c|c|c|}
\hline \multirow{2}{*}{ Larutan } & \multirow{2}{*}{ No } & \multicolumn{2}{|c|}{$P=90 \mathrm{mmHg}$ (konstan) } \\
\cline { 3 - 4 } & & $h(\mathrm{~m})$ & $\begin{array}{c}V(\text { Laju } \\
\text { tetesan }) \\
(\mathrm{m} / \mathrm{s})\end{array}$ \\
\hline \multirow{2}{*}{$\mathrm{NaCl}$} & 1 & 1,1 & 2,93449 \\
\cline { 2 - 4 } & 2 & 1,2 & 3,25466 \\
\cline { 2 - 4 } & 3 & 1,3 & 3,54604 \\
\hline \multirow{2}{*}{$5 \%$} & 1 & 1,1 & 2,94649 \\
\cline { 2 - 4 } $5 \%$ & 2 & 1,2 & 3,26908 \\
\cline { 2 - 4 } & 3 & 1,3 & 3,56258 \\
\hline
\end{tabular}

Solusi untuk menjaga laju tetesnya tetap stabil bagi pasien yang memiliki tekanan darah tinggi yaitu dengan mengubah ketinggian posisi botol cairan infus, dengan syarat bahwa variasi ketinggian diatas ketinggian normalnya. Rentang nilai variasi tekanan yang diberikan untuk masing-masing variasi ketinggian tersebut antara $80-100 \mathrm{mmHg}$, dan tekanan manometer yang digunakan pada variasi ketinggian ini sebesar $90 \mathrm{mmHg}$ dengan variasi ketinggian masing-masing 1,1 m, 1,2 $\mathrm{m}$ dan 1,3 m. Berdasarkan perhitungan dan eksperimen di peroleh hasil laju tetesan cairan infus seperti pada Tabel 3. Pada penelitian ini perlu adanya perbandingan laju tetesan cairan infus ketika tekanan dan ketinggiannya diubah. Perbandingan masing-masing variasi memiliki tekanan manometer pada eksperimen variasi ketinggian dan tekanan adalah konstan bernilai $65 \mathrm{mmHg}$. Ketinggian kedua variasi juga sama yaitu $h_{2}=1 m$ dan dengan jenis larutan yang sama. Perbandingan nilai laju tetesan cairan infus untuk masing-masing variasi dapat disajikan pada Tabel 4.

Tabel 4. Perbandingan nilai laju tetesan cairan infus terhadap variasi tekanan dan variasi ketinggian

\begin{tabular}{|c|c|c|c|}
\hline \multicolumn{3}{|c|}{ Laju tetesan Cairan Infus $(\mathrm{m} / \mathrm{s})$} \\
\hline Variasi Tekanan & Variasi Ketinggian \\
\hline $\mathrm{NaCl}$ & Glukosa & $\mathrm{NaCl}$ & Glukosa \\
$0,9 \%$ & $5 \%$ & $0,9 \%$ & $5 \%$ \\
\hline 3,47210 & 3,50580 & 3,04294 & 3,05836 \\
\hline
\end{tabular}

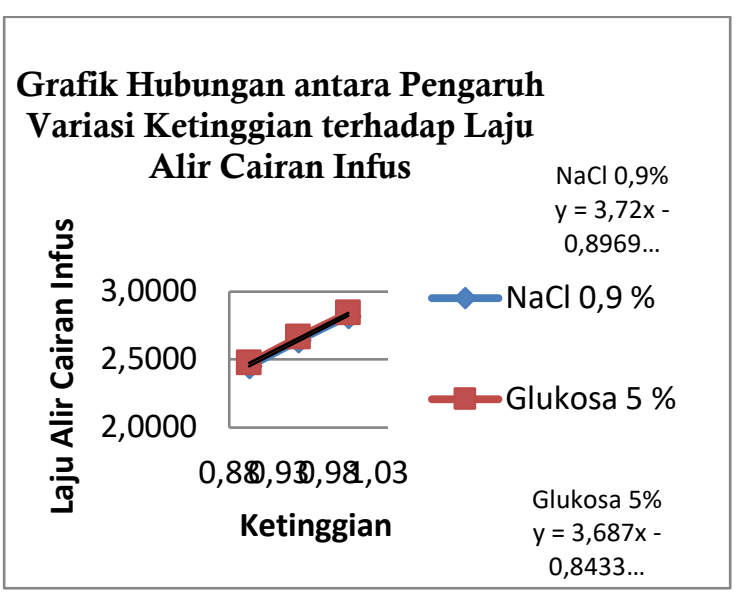

Gambar 3. Grafik hubungan antara laju alir dengan ketinggian letak tabung infus

\section{Penyebab Phlebitis}

Klasifikasi phlebitis berdasarkan penyebab menurut Infusion Nurses (INS, 2012) dalam Rohani (2016) terdiri dari phlebitis kimia, phlebitis mekanis dan phlebitis bakterial. Phlebitis mekanis sering dihubungkan dengan penempatan kateter intravena. Kateter intravena yang ditusukkan pada daerah lekukan atau area fleksi beresiko terjadinya phlebitis yang disebabkan karena pada saat ekstremitas digerakkan kateter intravena yang terpasang ikut bergerak, menyebabkan trauma pada dinding vena. Ukuran kateter intravena dipilih sesuai dengan ukuran vena dan dofoksasi dengan baik. Penggunaan kateter intravena yang besar pada vena yang kecil dapat mengiritasi dinding vena (The Center for Disease Control and Prefention (CDC,2012)). Sehingga fokus dalam penelitian 
ini adalah memperhitungkan laju alir caiaran infus pada vena pasien dengan kondisi memiliki riwayat hipertensi.

\section{Riwayat Hipertensi}

Phlebitis ditinjau dari faktor penyebabnya terutama yang terkait dengan host yaitu karakteristik pasien sering dikaitkan dengan usia, jenis kelamin, status gizi dan penyakit kronis seperti hipertensi, diabetes melistus, gagal ginjal kronik, kanker (Rizky. 2016).

Sistem imunitas dalam tubuh mempunyai fungsi yang kompleks, salah satunya adalah sebagai banteng pertahanan utama dari adanya invasi dan infeksi oleh mikroorganisme, jamur, parasit, dan virus dengan mengidentifikasi dan membunuh substansi pathogen (Isfandiari dan Akbar, 2018). Mekanisme imunitas didalam tubuh dari infeksi adalah pembentukan antibodi (immunoglobin), seiring dengan bertambahnya usia, akan terjadi berbagai kemunduran pada organ tubuh yang menyebabkan tubuh rentan terkena infeksi dan penyakit. Gangguan yang sering ditemukan adalah gangguan seperti hipertensi (Andria (2013) dalam Isfandiari dan Akbar (2016)).

Menurut Rizky (2016) dalam Isfandiari dan akbar (2018) diperoleh hasil penelitian didapatkan bahwa sebagian besar pasien yang terdiagnosa phlebitis menderita hipertensi dengan persentase sebesar $75,60 \%$ dan OR sebesar 6,18 yang artinya pasien dengan hipertensi mempunyai resiko 6,18 kali mengalami infeksi phlebitis dibadingkan dengan pasien yang tidak hipertensi, yang menyatakan bahwa $38 \%$ responden menderita hipertensi dan terinfeksi phlebitis.

Hasil penelitian Isfandiari dan Akbar (2018) pada riwayat hipertensi menunjukkan nilai signifikansi sebesar $0,01(\mathrm{p}<0,05)$ yang berarti bahwa status hipertensi juga ikut berpengaruh terhadap kejadian phlebitis.

Berdasarkan hasil penelitian Agustini, Utomo dan Agrina (2013) didapatkan data bahwa responden yang sering mengalami phlebitis berada pada rentang usia lansia yaitu sebanyak 17 orang $(85 \%)$ dan deawasa yaitu sebanyak 3 orang (15\%) sedangkan pada remaja tidak terdapat kejadian phlebitis, dengan pengaruh bermakna yakni $p$ value $=0,000$. Hasil tersebut menginformasikan bahwa terdapat hubungan antara kategori peningkatan usia dengan phlebitis. Kejadian phlebitis didahului dengan adanya thrombus yang ada didinding vena. kejadian thrombus pada vena meningkat pada usia $>40$ tahun. Setelah dilakukan beberapa penelitian pasien terdiagnosa phlebitis menurut Akbar et. Al. (2018) bahwa distribusi karakteristik pasien yang terpasang kateter intravena menunjukkan bahwa sebagian besar pasien yang terdiagnosis phlebitis pada bulan Januari-April 2017 di RSU Haji Surabaya yaitu pasien berusia $\geq 60$ tahun, jenis kelamin perempuan, malnutrisi, menderita hipertensi dan diabetes melitus.

\section{KESIMPULAN}

Berdasarkan hasil penelitian yang dilakukan, dapat disimpulkan bahwa dari simulasi pemodelan fisis alat terapi intravena dengan variasi tekanan dan ketinggian mempengaruhi laju aliran caiaran infus. Perbandingan laju tetesan cairan infus menunjukkan linearitas terhadap variasi tekanan dan ketinggian. Hasil laju tetesan cairan infus diperoleh berbanding terbalik dengan nilai tekanan diastolik. Semakin besar tekanan diastolik, akibatnya memperlambat laju tetesnya, sedangkan hasil laju tetesan cairan infus menunjukkan linearitas yang besarnya sebanding dengan meningkatnya nilai variasi ketinggian. Jadi dalam menjaga laju tetesan cairan infus agar tetap stabil bagi pasien yang memiliki tekanan darah tinggi, adalah dengan mengubah ketinggian posisi botol cairan infus, dengan syarat bahwa variasi ketinggian diatas ketinggian normalnya. Sehingga untuk mencegah adanya turbulensi cairan infus (faktor penyebab phlebitis) dengan menaikkan standard lokasi pemasangan infus pasien. Hal ini dapat dilakukan terkecuali bagi pasien 
dengan usia lanjut terkendala pada rongga pembuluh vena yang semakin usia terdapat faktor penebalan pada dinding vena.

\section{SARAN}

Bagi rumah sakit hasil penelitian ini dapat digunakan sebagai masukan dan pertimbangan dalam melakukan tindakan perawatan pada pasien yang trepasang infus dengan memperhatikan faktor-faktor mekanik yang mempengaruhi terjadinya phlebitis pada pasien yakni usia dan riwayat hipertensi. Penelitian ini diharapkan dapat dijadikan sebagai acuan untuk selalu menaikkan standard keperawatan di rumah sakit.

\section{UCAPAN TERIMAKASIH}

Ucapan terimakasih kepada semua pihak yang telah membantu dalam penelitian ini.

\section{DAFTAR PUSTAKA}

Akbar N.M.F.H., Isfandiari, M.A. 2018. Pengaruh karakteristik pasien yang terpasang kateter intravena terhadap kejadian phlebitis. Jurnal Berkala Epidemiologi, 6 (1): 1-8.

Agustini C., Utomo W., dan Agrina. 2013. Analisis factor yang berhubungan dengan kejadian phlebitis pada pasien yang terpasang infus di ruang medical chtysant Rumah sakit Awal Bros pekanbaru. JOM PSIK. 1 (2): 1-9.

Alexander, M, Corrigan, A, Grski, L, Hankins J., \&Perucca, R., 2010. Infusion nursing society, Infusion nursing: An evidencebased approach. $3^{\text {rd }}$ edition. St. Louise : Dauders Elsevier.

CDC. 2017. Guidelines for the prevention of intravascular catheter-related infections. Departement of Health and Human Services . Washington DC.
Darmadi. 2008. Infeksi nosokomikal problema dan pengendaliannya, Jakarta : Salemba Medika.

Potter, P.A., \& Perry A. G. 2005. Fundamentals of nursing. $6^{\text {th }}$ Edition. Philadelphia : Mosby Inc.

Potter, P.A. \& Perry, A.G. 2006. Buku ajar fundamental keperawatan, konsep, proses dan praktik. Edisi 4 Volume 2 Jakarta : EGC

Pradini, P.C.A., 2016. Faktor-faktir yang berhubungan dengan kejadian phlebitis pada pasien rawat inap di RSUD Tugurejo Semarang. Skripsi. Fakultas Ilmu Keolahragaan,. UNNES. Semarang

Putri, I.R.R. 2016. Pengaruh lama pemasangan infus dengan kejadian flebitis pada pasien rawat Inap di Bangsal Penyakit Dalam dan Syaraf Rumah sakit Njur Hidayah Bantul. Jurnal Ners dan Kebidanan Indoensia, 4 (2) : 90.

Rizky, W. 2016. Analisis factor yang berhubungan dengan kejadian phlebitis pada pasien yang terpasang kateter intravena di Ruang Bedah Rumah Sakit Ar.Bunda Prabumulih. Jurnal Ners dan Kebidanan Indonesia, 4 (2): 102-108.

Rohani. 2016. Hubungan Lama Pemasangan Infus dengan terjadinya phlebitis di RS Husada Jakarta tahun 2015. Jurnal Ilmiah WIDYA, 3 (4): 1-8.

RSU Haji Surabaya. 2016. Laporan kejadian phlebitis RSU Haji Surabaya. Unit Pencegahan dan Pengendalian Infeksi (PPI) Rumah Sakit Umum Haji. Surabaya.

Seleky, W., Kumaat, L.T., \& Mulyadi. 2016. Pengaruh Teknik penyunyikan intravena dengan cara mengalirkan infus terhadap kejadian phlebiytis di Ruang Perawatan 
Jurnal SainHealth Vol. 5 No. 1 Edisi Maret 2019

(C) Fakultas Ilmu Kesehatan Universitas Maarif Hasyim Latif Sidoarjo

p-ISSN : 2548-8333

e-ISSN : 2549-2586

Bougenvile RSUD Tobelo. E-Journal

Indramayu. Thesis. Magister Ilmu

Keperawatan (e-Kp), 4(1), 1-8.

Keperawatan FIK UI. Jakarta

Wahyunah. 2011. Hubungan Pengetahuan perawat tentang Terapi Infus dengan kejadian phlebitis dan kenyamanan pasien dirunag rawat inap Rumah Sakit Umum Daerah (RSUD) Kabupaten 